\title{
THE FOURTH EUROPEAN CONGRESS OF CARDIOLOGY
}

The fourth European Congress with over one thousand delegates present took place in Prague from August 17-21, 1964. Professor Pavel Lukl, the President, and Associate Professor H. Kafka, the General Secretary, deserve great praise for their successful organization of the largest European Cardiological Congress yet held.

In his opening address Professor Lukl set the tone for the whole meeting when he said "We here in Prague call this ancient city the heart of Europe, which may be true not only in the geographical sense but also as a peaceful meeting point of East and West". It was in this atmosphere of European co-operation and united endeavour that the conference took place. Professor Lukl also referred to his original intention of strict limitation of papers but pointed out that this had not always been possible as in some instances acceptance of a communication was the only condition which enabled the author to attend the meeting. In spite of these and other difficulties the papers were on the whole well selected and well delivered.

The meeting took place in four auditoria; two were in the Central Concert Hall of the House of Artists and two were in the buildings of the Faculty of Law of Charles University, which was some three minutes' walk from the Concert Hall along the banks of the Vltava. A good telephone system between the four lecture halls with indicator boards displaying the numbers of the communications being given in each hall made it possible for delegates to plan their daily programme with ease. Papers began at 8.30 in the morning and did not finish until after 6.00 in the evening, but the meetings were so arranged that one afternoon was free. Thus, even the most ardent cardiologist could enjoy the beauties of Prague for at least half a day with a clear conscience.

Various aspects of coronary artery disease and hypertension were prominent features in the programme as were the important therapeutic advances that had taken place since the last European Congress. These included the use of countershock for arrhythmias, artificial pacemakers for complete heart block, and further developments in resuscitation. There were comparatively few contributions on cardiac surgery. Aortic and mitral valve replacement received little attention, which was a sad, but accurate reflection of European achievement in this field during the past four years. In addition to individual communications, twelve of which came from members of the British Cardiac Society, there were symposia on various subjects including Metabolic Disorders of the Myocardium, Pathophysiology of the Pulmonary Circulation, Assessment of Central Hæmodynamics, Epidemiology of Atherosclerosis, Surgery of Mitral and Aortic Incompetence, and finally Prevention and Rehabilitation in Cardiology. Some of these symposia were very successful but others tended to be reviews of established work to the exclusion of more recent and controversial aspects of the subject. In addition there were four main lectures during the conference; these were given by Lenègre (France), Rijlant (Belgium), Parin (USSR), and Condorelli (Italy). Parin's lecture on the Cardiovascular System in Interplanetary Space described the means of monitoring cardiovascular physiology from "outer space"; this was impressive and though details were scant one was left with the notion that the Russian astronaut was a man whose heart and circulation were remarkably little disturbed by this mode of travel.

Prague is one of the most beautiful and ancient cities in Europe. Its buildings, some of which date back to the foundation of the New Town in 1348, are virtually unscathed by recent wars. The ladies (and some of the delegates) under the guidance of Madam Luklova and her committee had many opportunities of exploring the city. The social programme also included tea on the terrace of the Strahov Monastery-now a National Library-overlooking the city, visits to nearby castles, a 
convincing display of historical fencing, and a fashion show. Evening entertainments were numerous and varied-a concert by the Czech Philharmonic Orchestra, a recital by the Smetana Quartet, Songs and Dances by the State Company, a concert by the Czech Choir and the Laterna Magicaa modern synthesis of ballet, screen, and comedy. The absence of an official banquet was a pleasant change. Its place was taken by a most lavish and enjoyable Closing Ceremony held in the great hall of the Czernin Palace where wine flowed and hospitality continued until the early hours of the morning.

As the Prague Congress of 1964 takes its place with its predecessors held in London, Stockholm, and Rome, we should like to record our appreciation and gratitude to the many hosts, both official and unofficial, who contributed so much to the success of this meeting.

RICHARD EMANUEL 